\title{
Headset Device
}

National Cancer Institute

\section{Source}

National Cancer Institute. Headset Device. NCI Thesaurus. Code C49982.

An accessory for a telephone that is worn on the head and designed to allow hands free conversation. 